\title{
EFFECTIVENESS OF FLIPPED SMALL GROUP TEACHING IN UNDERSTANDING PRACTICAL KNOWLEDGE IN MICROBIOLOGY.
}

KEY WORDS: Medical education, Flipped small group teaching, Microbiology,

\section{Dr. Swapna \\ Kanade*}

\section{Dr. Gita Nataraj}

M.D. Microbiology, Associate Professor, Dept. of Microbiology, Seth G.S.Medical College \& KEM Hospital, Mumbai 400012. Maharashtra, India. *Corresponding Author

M.D. Microbiology, Professor and Head Dept. of Microbiology, Seth G.S.Medical College \& KEM Hospital, Mumbai 400012. Maharashtra, India.

Flipped Classroom is a new technique used in teaching. This study is conducted to determine if a flipped small group discussion is an effective learning method for undergraduates learning clinical microbiology, as compared to traditional practical class in achieving improved understanding, retention and greater satisfaction in the students and to evaluate this system through student feedback.

The study was initiated after Institutional Ethics Committee's approval. Materials were developed and validated before commencement of the study. A total of 144 students were included in the study. A 45-minute lecture by a faculty on the selected topic was taken for all the students after which the students were randomly assigned to the groups $A$ or $B$ as follows: Group A: Flipped small group teaching, Group B: Traditional practical class. Validated material of the practical class was send to students of group A one day before of practical class by email. The same was also made available to teachers. Flipped small group teaching and traditional practical class was conducted on the same day for group A and B respectively. After the session, the students administered the performance test as well as the feedback form. Surprise performance test was re-administered to the same students at the end of 15 days to test for subject retention.

Results: Significant increase in the marks of the performance test was observed in the group " $A$ " students as compared to group B students in both first and second test. The feedback given by the students about subjective learning experiences in terms of the enjoyment of the new technique, attention, comfort, and increase in the confidence, participation and whether they would like further learning using the same format definitely had a higher score in Groups A compared with Group B

Conclusions: Use of Flipped classroom approach in health education yields a statistically significant improvement in learner performance compared with traditional teaching methods. Use of mobile phone or computer is more acceptable to the students than traditional didactic approach.

\section{INTRODUCTION}

The society requires competent doctors who deliver safer, high quality and more cost-effective patient care. The current healthcare system is undergoing transformation to achieve this goal. The teaching done in medical education can contribute a lot for this transformation [1]. Microbiology teaching for MBBS student is done as a lecture for large group or as practical session for small group. As microbiology practical is conducted usually in the afternoon session, it is necessary to make it more interesting and interactive. Otherwise students remain inattentive leading to less understanding of microbiological aspects of infectious disease and poor retention of knowledge. This reflects in poor knowledge of management and control of infectious disease.

With the advancement of technology in the new millennium, students have access internet at the tip of their fingers [2]. Flipped Classroom (FC) model is a technique that was introduced by Jonathan Bergmann and Aaron Sams in early 2000 [3]. Core elements of an FC include assigned pre-class content, working on learning gaps, developing competency, and the teachers' role as guide on the side [4]. Flipped learning is an approach where the students are introduced to the learning material before class, with classroom time then being used to deepen understanding through discussion with peers and problem-solving activities facilitated by teachers. The study material can be provided in the form of reading articles, powerpoint slides or videos. The availability of study material before the scheduled class time can help students be not only acquainted with the topics ahead of time, but also self-paced and self-disciplined in a more learner-oriented manner $[5,6,7]$ Assuming students have utilized the teacherposted learning resources before in-class session, active learning strategies in the classroom offer opportunities for deeper understanding through application and analysis of the content.[8]

The lecture time is used for more engaged and active learning. Flipped classroom model is used mainly for conducting lectures for large number of students. Similar flipped concept can be tested for small group teaching in microbiology practical session. A small group teaching (SGT) includes 12-15 students where the teacher delivers practical knowledge of the topic with some demonstrations. It has been observed that the students are usually bored with this activity which occurs post lunch. This leads to lack of concentration, poor understanding and retention of the microbiological aspects of infectious disease. If SGT is done using flipped concept, it may result in more interaction and comfort level resulting in gaining more knowledge. Also the practical aspects of a topic like smears observed under the microscopes, tissue specimens and related case studies can be better discussed resulting in better retention of knowledge. Hence this study was conducted to determine if a flipped small group discussion is an effective learning methods for undergraduates learning clinical microbiology, as compared to traditional practical class in achieving improved understanding, retention and greater satisfaction in the students and to evaluate this system through student feedback.

\section{MATERIAL AND METHODS}

The study was initiated after Institutional Ethics committee approval. Materials were developed and validated before commencement of the study. The topic for the practical was finalized as Tuberculosis considering the routine teaching schedule of the students and the time required to prepare flipped study material, feedback form and the performance test.

\section{Development and validation of the study material for} flipped practical class.

Pictures, video and reference material related to the practical aspect of the topic was prepared by downloading from internet. Appropriate picture, video and powerpoint presentation were included in the flipped study material for 
that topic. Maximum time required to read the material was not more that 25 to 30 minutes. The flipped material was reviewed and compared with the traditional practical class model to ensure that same materials in covered in a comparable fashion. It was finalized in consultation with the teaching faculty of Microbiology department. It was validated by at least five teaching faculty from the department who have undergone at least the basic MCI course in Medical Education Technology which include atleast one senior person like associate professor or professor.

\section{Development of performance test.}

A 10 marks multiple-choice type test was developed to address the topic covered in the flipped SGT and traditional practical session. The questions were reviewed by several faculties trained in MET. A posttest was also administered 15 days later to all the students who attended flipped SGT and traditional practical session. Posttest consists of the same questions presented in a different order along with reordering of answer options.

\section{Development of the feedback form}

A feedback form was prepared which include 10 statements, each rated on a 5-point scale [1 (strongly disagree) to 5 (strongly agree)]. The feedback was taken using statements which explore participants' subjective learning experiences, satisfaction, comfort, confidence, bonding among them, feasibility, enjoyment and whether they would like to continue SGT using the same format. It was validated by at least five trained teaching faculty from the department.

\section{METHODOLOGY:}

Current second MBBS batch has total 180 students. All students were invited to participate in the study. 144 students who agree to participate in the study were given informed consent form and written informed consent was obtained from them. Randomization was done by computer method and they were divided into two equal groups. Flipped small group teaching was conducted for one group labeled as " $A$ " group and traditional practical class was conducted for second group labeled as group "B". Group B with traditional teaching was also exposed to Flipped small group teaching later (not included in study). Mobile phone number and email ID of all the participants in group $A$ was obtained. Five trained teaching faculty who validated the material required for the study were asked to conduct the traditional practical class as well as flipped SGT.

\section{Lecture}

A 45-minute lecture by a faculty on the selected topic was taken for all the students which include students of both group $A$ and $B$ as well as those students who had not participated in the study. All the students were provided with a similar baseline of knowledge of the topic at the same time before conducting practical by traditional method or flipped SGT.

\section{Practical Class:}

Practical class of both group A and B was conducted on the same day, at the same time and for the same period which is 1 hour 45 minutes. Flipped SGT was conducted during this routine practical class timing and not separately. Teaching, performance test and submission of feedback form was done during this period only.

\section{Group A - Flipped small group teaching:}

Validated material of the practical class was send to students of group A by email. The instructions to check their email and read the material for next day practical class was send by whats app message on mobile phone. Also it was highlighted not to share this material with their friends and attendance in the class is compulsory. It was given one day before the day of practical class. The same was also made available to teachers.

On the day of the flipped SGT, teacher again introduced the concept of flipped SGT. This sessions was conducted by the faculty who are a co-investigator in this study and have been actively involved in developing the material for this class. Teacher played the role of facilitator and guided the discussion. Students discussed all the aspect of the topic by using the material provided to them by email among themselves. All the students were encouraged to talk during discussion and clear the doubts if any from their batch mates. Teachers also cleared the doubts raised during discussion as well as guided the discussion to prevent any deviation from the topic. All the spots, slides and tissue specimens will be demonstrated.

\section{Group B - Traditional practical class:}

Traditional practical class was conducted for Group B. In this practical class, students were introduced to the topic at the time of practical only. Teacher taught them about the topic and showed them all the spots, slides and tissue specimens. If any student has any doubt, then it was clarified by the teacher. Otherwise there was no active participation of students and no discussion among students about the topic.

\section{First performance test:}

After the session was over, performance test was administered to the students of both the $A$ and $B$ batches. It consists of 10 questions of one mark each. All of them were either multiple choices or one line answer question. The result of this test was used to evaluate the understanding of the topic and satisfaction by the students.

\section{Feedback form:}

Feedback form was given to the students of both $A$ and $B$ batches. Participant feedback was used to evaluate the parameters about of the usefulness of students.

\section{Second performance test:}

A second surprise performance test was administered 15 days later to both $A$ and $B$ batches during regular practical timing. Both the tests had same questions but a different order both for questions and options for the answer also. The results of both the performance tests were compared to evaluate the retention of the knowledge of the topic.

\section{RESULTS}

The feedback from and performance test result of all 144 students was analyzed.

Both the groups were comparable in terms of their performance at the end of the activity as well as at the end of 15 days. Average score of both the performance tests is shown in the Table 1.

Table 1: Average score in the performance test

\begin{tabular}{|c|c|c|}
\hline Performance test & $\begin{array}{c}\text { Group A } \\
\text { (Flipped class) }\end{array}$ & $\begin{array}{c}\text { Group B } \\
\text { (Traditional } \\
\text { class) }\end{array}$ \\
\hline $\begin{array}{c}\text { First test (Immediately } \\
\text { after the practical class) }\end{array}$ & 8.93 & 6.4 \\
\hline $\begin{array}{c}\text { Second test (15 days } \\
\text { after the practical class) }\end{array}$ & 7.97 & 6.11 \\
\hline
\end{tabular}

Significant increase in the marks of the performance test was observed in the group " $A$ " students as compared to group B students in both first and second test.

Table 2: Comparison of feedback of students in group A and $B$

\begin{tabular}{|l|l|l|l|}
\hline $\begin{array}{l}\text { Sr. } \\
\text { No. }\end{array}$ & Questions & $\begin{array}{l}\text { Group A } \\
\text { (Flipped } \\
\text { class) }\end{array}$ & $\begin{array}{l}\text { Group B } \\
\text { (Traditional } \\
\text { class) }\end{array}$ \\
\cline { 3 - 4 } & & $\begin{array}{l}\text { Average score on 5 } \\
\text { point scale }\end{array}$ \\
\hline 1 & I found this method enjoyable & 4.7 & 3.9 \\
\hline
\end{tabular}




\begin{tabular}{|l|l|l|l|}
\hline 2 & $\begin{array}{l}\text { I was comfortable while } \\
\text { discussing the topic }\end{array}$ & 4.2 & 3.1 \\
\hline 3 & $\begin{array}{l}\text { This method increased my } \\
\text { confidence }\end{array}$ & 4.6 & 2.7 \\
\hline 4 & $\begin{array}{l}\text { I was attentive during full } \\
\text { session }\end{array}$ & 4.9 & 2.1 \\
\hline 5 & $\begin{array}{l}\text { The teaching method } \\
\text { facilitated my participation }\end{array}$ & 3.9 & 3.1 \\
\hline 6 & $\begin{array}{l}\text { The study material provided } \\
\text { before session was } \\
\text { appropriate }\end{array}$ & 4.4 & 4 \\
\hline 7 & $\begin{array}{l}\text { It assisted me in preparing for } \\
\text { practical class. }\end{array}$ & 4.3 & 4.4 \\
\hline 8 & $\begin{array}{l}\text { This method assisted in } \\
\text { clarifying my doubts about } \\
\text { the topic }\end{array}$ & 3.1 & 3.9 \\
\hline 9 & $\begin{array}{l}\text { This method will help me in } \\
\text { applying the knowledge } \\
\text { practically }\end{array}$ & 3.8 & 3 \\
\hline 10 & $\begin{array}{l}\text { I would like other topics to be } \\
\text { covered using the same } \\
\text { method }\end{array}$ & 4.8 & 2.7 \\
\hline
\end{tabular}

The feedback given by the students about subjective learning experiences in terms of the enjoyment of the new technique, attention, comfort, and increase in the confidence, participation and whether they would like further learning using the same format definitely had a higher score in Groups A compared with Group B (Table 2).

\section{DISCUSSION:}

Appropriate use of teaching learning (TL) method in medical teaching plays very important role in understanding of the subject by the students. More specifically, TL method used in small group teaching should be student centric yet able to deliver required knowledge effectively. Medical students are adult learner and current generation is techno-savvy having access to various social online platform. Use of computer and smart phone has become integral part of their life. The same can be used for teaching medical knowledge.

Considering the exhaustive syllabus of medical education, it is important to try new teaching learning methods that generate interest in the student's mind and help them to retain the knowledge also. The concept of "flipped classroom" or "inverted classroom." is a class where the lecture and homework have been reversed. [9] Thus, instead of students listening to a lecture in class and then going home to work on a set of assigned problems, they read course literature and assimilate lecture material through video at home before the actual class and engage in teacher-guided problem-solving, analysis and discussions in class. [10]

In this study, a significant increase has been observed in the performance score of the students in group A (flipped class) as compared to group B (traditional class). This finding was observed in both first as well as second test. Significant increase in the performance score in first test conducted immediately after the practical class indicates that understanding of the students was better in group $A$ than group B. The study material provided to the students was in the form of pictures and videos officially available on internet as well as power point presentation prepared by our faculty for teaching purpose only. It was provided one day before the teaching session and they could access it on their laptop or smart phone. All the students in group $A$ agreed that had read the study material.

Possible reason for better performance in first test may be because students can read the study material at home after the college time and comparatively in a relaxed atmosphere. Students have unrestricted access to videos, pictures and study material sent to them and they can access it learn anywhere and at any time, at their own pace [11]. Students can

also watch the videos multiple times to better understand a particular topic $[11,12]$. As a result of this preparation done one day before, they could get more time in class for active learning, clarifying their doubts and also promoted students' interactions with their peers. This helped to increase students' understanding of the subject material. [13]. A recent review of learner perceptions of flipped classrooms in health professions education [14] found an overwhelming positive response from students who attended flipped courses.

Improved performances of the students in second test indicate that there was better retention of knowledge. This was possible because students have spent more time on the topic both at home and during class. Also there was better understanding of the subject and doubts were cleared during discussion with peers. Also the visual impact of the material provided to them before class may have helped them to retain the important points in that topic. One explanation for this finding is that prior reading of topic helped students to recall the knowledge learned prior to the class. Prior knowledge has long been considered an important factor influencing learning $[15,16]$. Stimulating the recall of prior knowledge helps learners to make better sense of new information by connecting it to something they already know. In addition, the retrieval of information from memory makes the path to that information in memory stronger; this consequently enables the information to be more easily retrieved by the learner on the next occasion [17]. Thus the flipped classroom approach was more effective than traditional classroom in increasing student learning performance.

The feedback was obtained after the class from both group $A$ and group B. The information gathered during feedback was mainly about qualitative aspect of teaching method. It mainly stressed on the aspect like comfort, attentiveness and enjoyment while studying, confidence about understanding the topic and active participation during discussion. There was a significant difference seen in the feedback given by the students of group A as compared to group B. Few students in group A suggested that the study material can be sent after the class is over as it may reinforce the knowledge gained. But it is not possible to know whether the student has read the material after the class is over. If the study material is sent before class and student know that it will be discussed in the class, there is more chance that they will read it.

The limitation of our study is that it tests only cognitive domain of the knowledge in the first and second test and not the psychomotor domain.

Use of Flipped classroom approach in health education yields a statistically significant improvement in learner performance compared with traditional teaching methods. Use of mobile phone or computer is more acceptable to the students than traditional didactic approach.

\section{REFERENCES}

1. Mazur E.Education. Farewell, lecture? Science. 2009;323(5910):50-51.

2. Vindya Perera \& Nelun de Silva. Flipped Classroom Model for teaching and learning medical microbiology. The Asia Pacific Scholar, May 2017, Vol. 2 (2):24-29.

3. Lage MJ, Platt GJ, Treglia M. Inverting the classroom: a gateway to creating an inclusive learning environment.J Econ Educ. 2000;31(1):30-43.

4. Hurtubise et al. the flipped classroom in Medical education: Engaging Students to Build competency. Journal of Medical Education and Curricular Development 2015;2:35-43.

5. Chaya Gopalan and Megan C. Klann. The effect of ipped teaching combined with modi ed team-based learning on student performance in physiology. Adv Physiol Educ.2017,41:363-367

6. Gross D, Pietri ES, Anderson G, Moyano-Camihort K, Graham MJ. Increased preclass preparation underlies student outcome improvement in the ipped classroom. CBE Life SciEduc 14: ar36, 2015.

7. Hawks SJ.The ipped classroom:now or never? AANA J.2014:82:264-269.

8. Ash, K. (2012). Educators evaluate 'flipped classrooms'. Education Week, $32(02), 6-8$

9. Szparagowski, Raymond, "The Effectiveness of the Flipped Classroom" (2014). Honors Projects. 127.https://scholarworks.bgsu.edu/honorsprojects $/ 127$

10. Jalal Nouri. The flipped classroom: for active, effective and increased learning - especially for low achievers International Journal of Educational 
Technology in Higher Education (2016) 13:33

11. Giuliano CA, Moser LR. Evaluation of a flipped drug literature evaluation course. Am J Pharm Educ. 2016;80(4):66.

12. Cotta KI, Shah S, Almgren MM, Macías-Moriarity LZ, Mody V. Effectiveness of flipped classroom instructional model in teaching pharmaceutical calculations. Curr Pharm Teach Learn. 2016;8(5):646-53.

13. Galway LP, Corbett KK, Takaro TK, Tairyan K, Frank EA. Novel integration of online and flipped classroom instructional models in public health higher education. BMC Med Educ. 2014;14(1):181.

14. Ramnanan CJ, Pound LD. Advances in medical education and practice: student perceptions of the flipped classroom. Adv Med Educ Pract. 2017;8:63-73.

15. Hailikari T, Katajavuori N, Lindblom-Ylanne S. The relevance of prior knowledge in learning and instructional design. Am J Pharm Educ. 2008;72(5):113.

16. Merrill MD. First principles of instruction. Educ Technol Res Dev. 2002;50(3):43-59

17. Dirkx KJH, Kester L, Kirschner PA. The testing effect for learning principles and procedures from texts.J Educ Res. 2014;107:357-64. 